\title{
Galileo in Padua: architecture, fortifications, mathematics and "practical" science
}

\author{
Raffaele Pisano • Paolo Bussotti
}

Published online: 5 March 2015

(c) Centro P.RI.ST.EM, Università Commerciale Luigi Bocconi 2015

\begin{abstract}
During his stay in Padua ca. 1592-1610, Galileo Galilei (1564-1642) was a lecturer of mathematics at the University of Padua and a tutor to private students of military architecture and fortifications. He carried out these activities at the Academia degli Artisti. At the same time, and in relation to his teaching activities, he began to study the equilibrium of bodies and strength of materials, later better structured and completed in his Dialogues Concerning Two New Sciences of 1638. This paper examines important details of four works dating to the Paduan period: Breve instruzione dell'architettura militare; Trattato di Fortificazione; Le Mecaniche; Le operazioni del compasso geometrico et militare. The two works on military architecture and fortifications were compiled from notes taken by students, and are not by Galileo's hand, but are still illustrative of his work and thinking at the time.
\end{abstract}

Keywords Galileo - Architecture - Fortifications · Mechanics - Science in context $\cdot$ History of science . Military compass

\section{Background}

During his period in Padua, roughly from 1592 to 1610 , Galileo Galilei (1564-1642) read mathematics at the

\author{
R. Pisano $(\bowtie)$ \\ Department of Physics, University of Lille 1, Bât P5 bis Bureau \\ 168, 59655 Villeneuve d'Ascq Cedex, France \\ e-mail: pisanoraffaele@iol.it \\ P. Bussotti \\ Federigo Enriques Institute, Via della Bassata 21, \\ 57126 Livorno, Italy \\ e-mail: paolobussotti66@gmail.com
}

university, and was a private lecturer in military architecture and fortifications. These activities were carried out essentially at the Accademia degli Artisti. These were the years in which he began to study the motion and equilibrium of bodies (for example, the resistance of materials), studies that would be presented in a complete and integrated way in his Discorsi e dimostrazioni intorno a due nuove scienze (1638); they were the years in which he consolidated his Copernican beliefs-although he publishing nothing regarding this-and in which he would devote three lectures to the "new star" that appeared in the sky in October 1604, assumed by Galileo to be proof of the mutability of the heavens, in contrast to the convictions of the Aristotelian school. Countering Galileo, in 1605 Baldassarre Capra (1580-1626) published his Consideratione astronomica sopra la nova et portentosa stella che nell'anno 1604 a dì 10 ottobre apparve. Con un giudicio dei suoi significati, a work in which, in addition to giving his interpretations, Capra accused Galileo of having reported the star's position superficially and erroneously, of misunderstanding fundamental concepts such as parallax, and of not knowing how to apply mathematics to astronomy. Galileo replied with the cutting Dialogo di Cecco de Ronchitti in perpuosito della stella nuova (published that same year, 1605, in the Venetan-Paduan dialect), a work marked by the ironicpolemic vein that characterised a large part of his later works, and whose aim is to show that Capra's criticisms were unfounded. In July 1609, thanks to his friend Paolo Sarpi (1552-1623), Galileo learned of the existence of the telescope, perfected it, and presented it to the Doge, Leonardo Donato, and the Senate. The other dignitaries were amazed and admiring of the invention; they doubled Galileo's stipend, and ordered him to prepare twelve instruments, which were deemed very useful for military 
purposes. Galileo pointed the instrument to the heavens, arriving to the admirable discoveries set out in his Sidereus Nuncius (1610). This brief treatise, brought out by the publishing house Baglioni with an initial print run of 550 copies, became the first scientific bestseller. The copies were sold out in just a few days, and thanks to Sidereus Nuncius, Galileo would shortly become perhaps the most famous scientist in Europe.

In Padua, after the inaugural lecture at the university on 7 December 1592 , he officially began his teaching a week later: in this period and in correlation with his teaching, he analysed Euclid's Elements and Theorica planetarum, Sacrobosco's De Sphaera, the Aristotelian School's Questiones Mechanicae, commenting as well on their De Coelo, and Ptolemy's Almagest, thus providing his students with a complete picture, albeit one that was in line with the classics. $\mathrm{He}$ did not enter into questions such as the validity of the different world systems or the criticisms of Aristotelian physics.

In his years in Padua Galileo also undertook his first studies of the theory of motion and the equilibrium of bodies (in particular, on the resistance of materials). These studies would later be expounded in complete form in his Discorsi e dimostrazioni matematiche intorno a due nuove scienze published in 1638.

Galileo also devoted himself to privately tutoring students who were technically oriented, mostly sons of wealthy families of Venice and often foreigners, many of whom came from across the Alps. They were interested in questions of engineering and architecture, in military techniques, in the use of instruments for measuring and machines that were useful in civil or military fields. Galileo thus dedicated his private lessons to these topics rather than to questions of a theoretical nature. Besides, as is known, the interests of the scientist from Pisa were far from limited to theoretical problems. For him the Venice arsenal was a source of fundamental inspiration: the work of the artisans; the study of the ways in which ships were built; machines of all kinds, such as those for raising or transporting heavy weights, and the search for instruments that might facilitate, improve and make human labour more precise. The famous beginning of the Discorsi e dimostrazioni intorno a due nuove scienze confirms this:

The constant activity which you Venetians display in your famous arsenal suggests to the studious mind a large field for investigation, especially that part of the work which involves mechanics; for in this department all types of instruments and machines are constantly being constructed by many artisans, among whom there must be some who, partly by inherited experience and partly by their own observations, have become highly expert and clever in explanation [logical argumentation]. ${ }^{1}$

This quotation, in addition to constituting a fascinating incipit by a true master of the art of writing, reflects Galileo's deepest scientific convictions and is a sincere homage to the period he spent in Padua and Venice, and above all to everything that he had learned in the Arsenal. It is almost as though what he called Mecanica, which, up to Galileo, was essentially the art of understanding the function and construction of machines, was explored also on the basis of what was then the foundations of natural philosophy: physics. One example is the principle of the lever (and the related study of the centre of gravity) applied to one or more weights (force-weight), a principle of the earlier "science of weights" [26], underlying the mechanisms of machines and therefore later of mechanics, hence the connection between practice and theory in architecture-engineering and mechanics. It is no coincidence that Galileo's long-time collaborator was neither another scientist nor a mathematician, but rather a very skilful craftsman, Marcantonio Mazzoleni (d. 1632). Mazzoleni lived with his wife and children in Galileo's house from 1599 to 1603 , and constructed a series of instruments for him.

Galileo's private lessons on fortifications, including military architecture as well as the works on machines and the proportional compass, also represented a source of supplementary income.

In this article we will provide a general description and examination of some of the important details of the four works dating to the period in Padua, of which the first two, untitled, have come down to us in the Opere Nazionali (Galilei Opere) only in the form of didactic lecture notes (and thus not autograph). It was only for editorial reasons that Antonio Favoro collected them (Galilei Opere II, p. 9), entitling them as though they were written by Galilei himself and inserting them among his publications. Here we will discuss:

Breve instruzione dell'architettura militare (Brief instructions on military architecture);

Trattato di Fortificazione (Treatise on Fortifications);

Le Mecaniche (Mechanics);

Le operazioni del compasso geometrico et militare (Operations of the geometric and military compass).

\footnotetext{
${ }^{1}$ Largo campo di filosofare a gl'intelletti specolativi parmi che porga la frequente pratica del famoso arsenale di voi, Signori Veneziani, ed in particolare di quella parte che mecanica si domanda; atteso che quivi ogni sorte di strumento e di machina vien continuamente posta in opera da numero grande d'artefici, tra i quali, $e$ per l'osservazioni fatte dai loro antecessori, e per quelle che di propria avvertenza vanno continuamente per se stessi facendo, è forza che ve ne siano de i peritissimi e di finissimo discorso (Galilei, Opere, VIII, p. 49; Eng. trans. [5], p. 1).
} 
These works are quite different, first of all because of the way they have come down to us, but also because of style and objects. Nevertheless, we believe that they are united by a common leading thread, which is the role of science, as it was then known, as the application in other disciplines that are of great interest with regard to the relationship between science and society as well.

\section{Introduction to the four works}

In this section we will provide general details about the four works, relative to how they have come down to us, their publication, and their contents.

\subsection{Breve instruzione dell'architettura militare}

Breve instruzione dell'architettura militare (Brief instructions in military architecture) (Galilei Opere, II, pp. 17-75) dates in all likelihood to the first year of Galileo's teaching in Padua, that is, from 1592 to 1594. It is not autograph [14, 23], but is instead a set of notes, rather well ordered, taken by students during Galileo's lessons on military architecture and fortifications, as emerges from the copies of the manuscripts conserved at the Biblioteca Ambrosiana (Galileo fl. 16th) in Milan and in the possession of Raffaele Pisano: the different manuscripts (there are several manuscripts, probably because they come from different students) are very similar in structure, and thus it appears that their compilation was pre-established, perhaps by Galileo himself, but we have no historic proof of this. Treatises on fortification constitute a genre of text whose form, in the second half of the 16th century, had already been consolidated by tradition. To cite only one example of treatises written or published beginning in the 1560 s, we mention the monumental Della fortificazione delle città by Giacomo Castriotto (1510-1563) and Gerolamo Maggi d'Anghiari (1523-1572), edited and published by the former in 1564 . In 1570 in Venice Galasso Alghisi da Carpi (1523-1573) published his ponderous Delle Fortificazioni, in three books. In 1573 appeared the English translation by Thomas Blundeville of an earlier treatise on fortification, Trattato sulle fortificazioni, a manuscript compiled by Jacopo Aconcio (1520?-1567). In 1596, again in Venice, Bonaiuto Lorini (c. 1540- c. 1611) published a treatise in five books that was destined to become famous, Delle fortificationi. Earlier still, Niccolò Tartaglia (1499-1557) in his La nova scientia (1537), had addressed some of the topics that would later be treated by Galileo; it is highly probably that Galileo was directly influenced by Tartaglia [26], even though he is never named in Galileo's treatises on fortifications. Therefore, the arguments and topics dealt with by Galileo were not entirely original in terms of general content; perhaps they were only original in the pedagogical, didactical way in which he presented them, seeing as how his background as a teacher was not that of an architect or engineer, or as a "man of war", as Bertrand Gille wrote with regard to the engineers of the Renaissance [10]. The study of fortifications was rapidly evolving at the time, and Galileo attempted to offer his students a problematic frame of reference regarding the art of artillery, in terms of attack and defense: walls, bulwarks, orillions, firing, restructuring of medieval fortifications, casemates, treason, mines, graphic scales.

On the level of contents, the Breve instruzione opens with a didactic summary of Euclidean geometry, fundamental for the art of fortifications [22-24]. For example, Galileo explains how to divide a line segment or angle into two equal parts, how to draw lines parallel and perpendicular to a given line, how to construct regular polygons, rigorously where possible, and approximately where not. This is followed by a section introducing the student to the terminology used to describe fortifications and the different types of artillery. The remarks that constitute what must ideally be considered the third part of the treatise are the most extensive (Galilei Opere, II, pp. 32-42), and are as interesting as the section concerning defense because Galileo explains the best way to construct a defensive perimeter around a city. The method of learning is thus what we would call today "problem-based learning", such as how to construct the curtain, the bulwark, the lower piazza, the shoulder, the orillion and the buttresses, as well as the best placement of defensive artillery. Galileo then goes on to analyse the ditch and other structures, such as the cavaliero. The fourth part (pp. 42-57) is dedicated to techniques of assault: Galileo teaches the best way to construct trenches in order to advance, unseen, closer to the fortress to be attacked, and the technique of constructing the so-called forni to place the mines. This is followed by a section devoted to the artillery of the attackers, in particular, the best way to place the cannons to attack the fortress, but also how to position the pieces of artillery in order to render the battery of the defenders as inoffensive as possible. The written part (pp. 57-67) concludes with a fifth section, entitled Del fortificar la terra, in which Galileo provides precise information regarding the best materials for constructing piote, blocks, or bricks to be used in fortification, and about the instruments to be used to obtain the blocks or bricks. He concludes these course notes with a series of explanatory drawings (pp. 68-74) on how to restructure medieval fortifications with round towers. Geometry plays an important role in the determination of the most suitable structure based on the objectives to be met. The text ends with the following phrase, which Favaro used for the title of the editorial notes mentioned earlier: E questo basti per questa breve instruzione 
all'architettura militare (And this suffices for this brief instruction on military architecture) (Galilei Opere, II, p. 75).

We would like to reiterate that the two works on fortifications were assembled by Favaro beginning with manuscripts that were similar, and thus not from a single manuscript.

\subsection{Trattato di fortificazione}

Written in the same years as the Breve instruzione all'architettura militare, this work too is composed of manuscript notes taken by students of Galileo's, probably checked by the scientist, but this time intended for students of a more advanced level. In fact, the didactic treatment (for example, the absence of captions for the figures, etc.) confirm that this is what we today would call an advanced course of study. The Trattato di fortificazione (Galilei Opere, II, pp. 79-146) is thus more in-depth and refined that the previous text, compiled (as indicated by the students) for educational purposes [14]; (Pisano and Capecchi 2012). Further, Galileo adds a greater number of theoretical explanations; for example, he specifies qual sia l'offizio dell'architetto (what the architect's function is) and, when he goes on to speak of the different defensive elements of a fortress, his text provides more detailed explanations and artistic drawings. The reasons for the imperfections in the extremely important part of the fortification, the bulwarks, is explained with due attention to detail (pp. 94-98), retracing them back to considerations of a geometric nature. The discussions of how to place defensive elements are developed in a way that is rigorous and convincing (pp. 103-107) and greater attention is given to the best way to thwart an attempt to scale the walls and how to counter an attack by a zappa (pp. 108-109) with respect to their treatment in the Breve instruzione. Techniques of assault are also explained more completely. The two paragraphs dedicated to trenches and to ways of crossing the ditch (pp. 105-115) are admirable for their clarity and precision. The section entitled Delle misure particolari di tutti $i$ membri della fortezza (pp. 120-126) is a masterpiece on the level of didactics and explanation, because Galileo summarises the concepts set forth previously and, practically, presents a project for construction, like a true military architect. No less instructive and well done is the long section entitled Diversi esempi d'accomodar i corpi di difesa secondo la diversità de' siti (pp. 130-142), where he examines the best way to build defensive structures on plains, in mountains, near rivers or marshes, or at the seashore. Each situation is explained clearly and in detail. In both texts, the straight lines drawn to describe the trajectories of projectiles are sadly scientifically inadequate ([14, 23], 2012).

\subsection{Le mecaniche}

Le mecaniche (Galilei Opere, II, pp. 155-191; [6]) is a treatment of the functioning of several different machines. The date of composition is uncertain, but it was probably compiled around 1598. In this case as well the text is comprised of Galileo's lessons, most likely prepared for his private teaching. In contrast to the other two works just described, Le mecaniche were published in French in 1634 by Marin Mersenne (1558-1648).

Although this text is collocated in the Iuvenilia, in our opinion it is a very important work, one that is perhaps underestimated in Galileo's oeuvre: on the level of epistemology, here we find Galileo already writing of the relationships between sensate esperienze e dimostrazioni necessarie, sensate experience and necessary proofs (although he uses words that are slightly different, as we will see in Sections. "Breve instruzione dell'architettura militare" and "Le mecaniche", with respect to the famous terms we have just quoted, which were used in the letter to Christina of Lorraine in 1615 (Galilei Opere, V, [pp. 309-348] p. 316)). With regard to the content, the scientist clearly distinguishes the operations that are possible with the machines from those that are not, arriving at the formulation of a series of principles of functioning for the machines that excludes a perpetual motion, even though they are not expressed explicitly in this form. Galileo underlines how the builders of machines are often engaged in the attempt to construct machines that are supposed to carry out operations that are impossible. This is due to the fact that the builders are, generally speaking, ignorant of the basic principles of physics. Further, here Galileo arrives at the formulation of propositions that are very close to the principle of inertia. There are thus multiple starting points for reflections offered in Le mecaniche, and in addition to the general ones of which we have spoken, there are also the clear explanations provided by Galileo of the way in which the machines he deals with work. These are: (1) the steelyard and the lever; (2) the axle of a wheel and the hoist; (3) taglie (which comprise pulleys and systems of pulleys); (4) the screw; (5) Archimedes' screw. He closes with a brief section on the force of impact. Le mecaniche thus presents, in nuce, a series of starting points and concepts that will form the bases of Galileo's more mature speculations.

\subsection{Le operazioni del compasso geometrico et militare}

There is a strange story behind the military compass, as an instrument and as a published text. Galileo ideated his military compass instrument in 1597 and between 1598 and the years that followed-according to the reliable testimony of Gerolamo Tiraboschi (1731-1794)-instructed several 


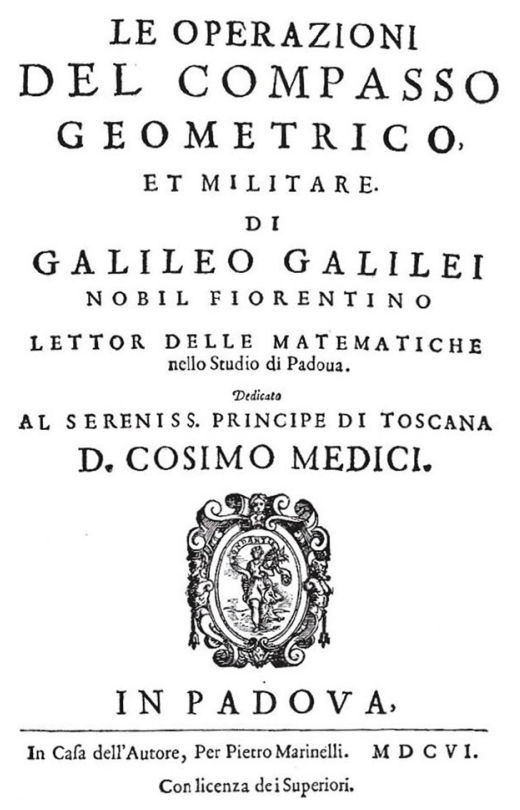

LE OPERAZIONI

DEL COMPASSO

ET MILITARE.

D I
G A L I L E O G A L I L E I
NOBIL FIORENTINO
DELLE MATEMATICHE
Dedicato

SERENISS. PRINCIPE DI TOSCANA

In Cafa dell'Autore, Per Pietro Marinelli. M D C V 1.

Con licenza dei Superiori.

Fig. 1 Images of the dispute between Galileo and Capra regarding the proportional compass (from left to right): a Galileo Galilei, Le operazioni del compasso geometrico e militare (1606); b Baldassarre
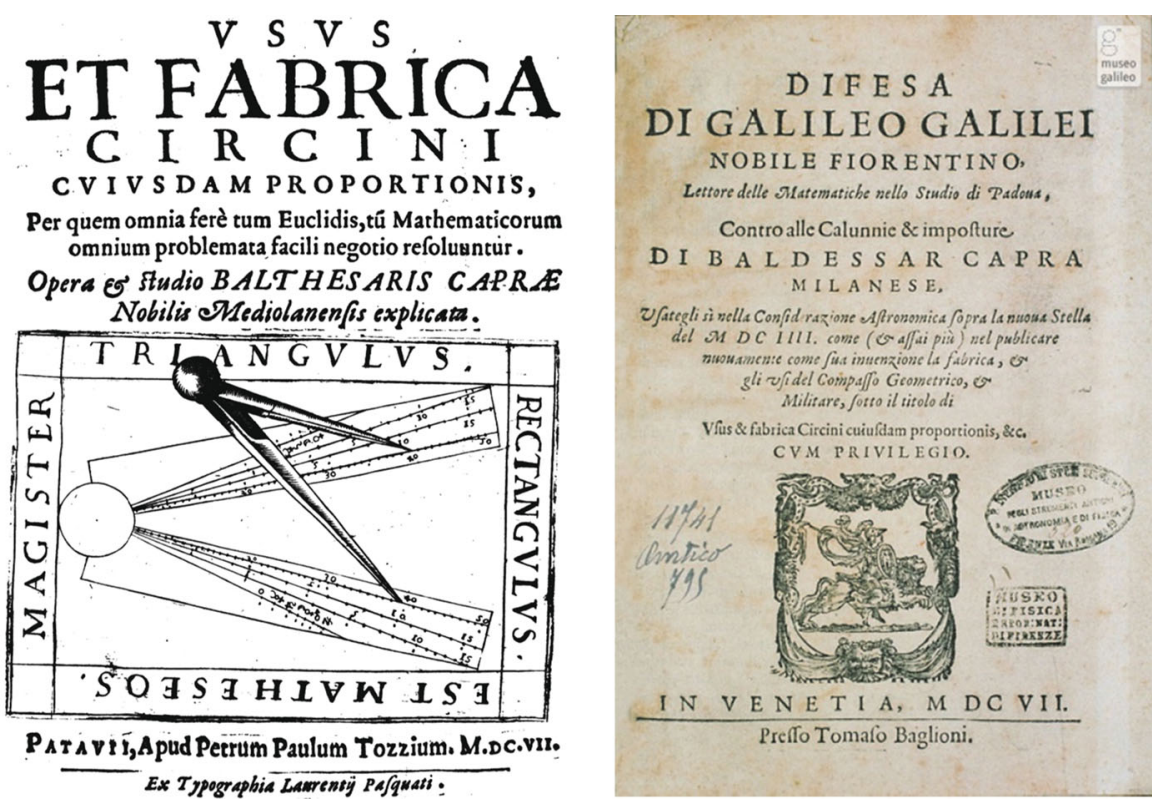

Capra, Usus et fabrica circini cuiusdam proportionis (1607); c Galileo Galilei, Difesa contro le imposture et calunnie di Baldassarre Capra (1607)

European sovereigns in its use, including Prince Giovanni Federico of Alsace, Archduke Ferdinand of Austria, Philipp, Landgrave of Hesse, and the Duke of Mantua. In 1606, Galileo, encouraged by the success of his instrument, published the brief treatise entitled Le operazioni del compasso geometrico et militare. The following year Baldassarre Capra, whom we have already encountered, took to print his Usus et fabrica circini cuiusdam proportionis, per quem omnia fere tum Euclidis, tum mathematicorum omnium problemata facile negotio resolvitur, which, practically speaking, was a translation into Latin of Galileo's work. Capra claimed priority for the invention of the devise and accused Galileo of plagiary. Galileo replied, still in 1607, with his Difesa contro alle calunnie et imposture di Baldessar Capra, in which he defended himself against Capra's accusations and accusing him in his turn. The affair took a legal turn, and the battle was won by Galileo, who was credited for the priority of the invention (Fig. 1).

This might therefore appear to be the usual story of plagiary and a dispute over priority. In reality, however, while it is true that Galileo can claim priority for the discovery over Capra, it certainly cannot be claimed that he was the inventor of the proportional compass. In effect, Thomas Hood (d. 1598) had published a text in 1598 on the geometric compass, and before him, in 1572 Fabrizio Mordente (1532-1608) had constructed a proportional compass for Emperor Maximillian II, described ten years later in a manuscript by his brother, Gaspare Mordente. There are testimonies of proportional compasses even earlier than this, but these permitted a number of operations that was inferior to what was possible with the Galileian compass. Galileo cannot therefore claim, in this case, priority for the discovery, but as is often the case with him, he could claim its refinement, its dissemination, and the detailed explanation of its function. Why is the geometric and military compass so important? Its importance is due to the fact that it makes it possible to carry out, by following a series of mechanical procedures, a plurality of mathematical operations-many of which go beyond what can be performed with only straightedge and compass-useful in military matters, even by those with a limited knowledge of mathematics. Practically speaking, it is an instrument whose function can be codified in a series of instructions that are easy to follow. Galileo proposed thirty-two of these operations, including: flat polygon, construct another similar to the first given a side homologous to one in the first polygon (operation III); extract the square root of a number (operation XII); a simple extension of the rule for the square root shows how to order the troops in a better way such that the array is in the form of a rectangle (operation XIII); extract the cube root (operation XVIII); find two mean proportionals between two segments (operation XIX); find the ratio between the specific weights of metals and other materials (operation XXII); divide the circumference of a circle as many equal parts as desired (operation XXVII). Galileo further explains that a quadrant can be added to the instrument in order to make other operations possible. One such operation that is particularly important in the military sector consists in the possibility of evaluating by sight the dimensions of objects that are far away, or in any case directly inaccessible. 


\section{Examples of some of the contents of the four works}

\subsection{Breve instruzione dell'architettura militare}

Let us consider an example concerning the best way to construct a bulwark that permits an optimal defense, in which we will underline a remarkable epistemological consideration on Galileo's part.

We begin with the construction of the bulwark. Galileo's explanation begins with a little nomenclature. Each line inclining on another and from which it is possible to see another line is called fianco (flank). The line to observe and protect, which is longer than the flank, is called cortina (curtain). Of the elements of defense, the most important is the baluardo (bulwark), which is comprised of two faces and two flanks as shown in the upper part of Fig. 2.

ALL' ARCHI'T'ET'TURA MULITARE.

bricati e di tal grandezza, che sieno capaci ed atti a tale ufficio, e di tal figura che possino ancora essi scambievolmente difendersi. E tutti questi fianchi, con tali regole fabbricati, si domandano corpi di difesa; i quali corpi sono molti e diversi, secondo ch' in diversi luoghi sono posti ed a diversi usi servono;

Tra tutti i corpi di difesa, il più importante è il bahuardo; il quale è costituito ${ }^{(1)}$ da due fianchi e due faccie, o fronti che dire le vogliamo; e si costuma fabbricarlo sopra li angoli delle cortine, come appresso si vede.

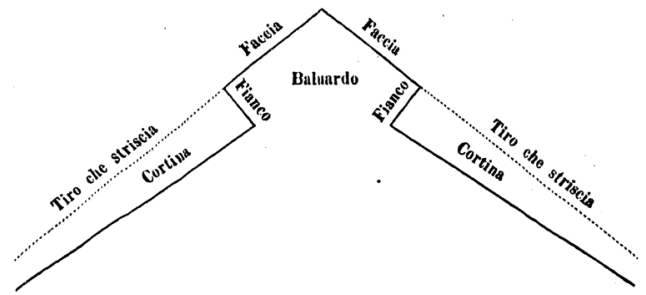

10 Nella fabrica de' quali due cose principalmente si avvertiscano: l' una $\grave{e}$, che i fianchi faccino angolo retto sopra la cortina; l'altra, che le faccie sieno vedute e difese dal fianco opposto, come per le linee punteggiate nella figura preposta si vede.

Seguono, appresso i baluardi, alcuni corpi di difesa chiamati piatteforme; le quali sono di due maniere, ciò è piattaforma e piattaforma rovescia. La piattaforma si usa fare tra l'uno e l'altro baluardo, e massime quando la cortina si riflette in dentro: e si costituisce an-

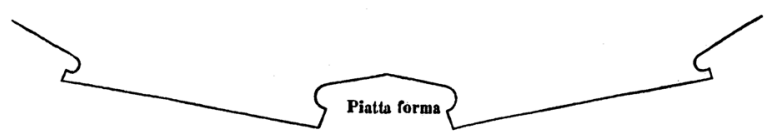

cora essa di quattro linee, ciò è di due fianchi e di due faccie; ed è differente dal baluardo, per esser più piccola e posta nell' angolo 20 interno della cortina, ed il baluardo su l'angolo esterno. La piat-

(1) Il cod. $A$ inserisce questo glossema: > guerlo dalla piatta forma, su l'angolo ester $<$ il quale è costituito (aggiungi, per distin- $\rightarrow$ no) da due fianchi e due faccie, ecc.s.

Fig. 2 In the upper part of the figure we see the bulwark, which defends the curtain with its flanks and its faces. The lines drawn parallel to the faces indicate the grazing fire, aimed at defending the curtain from an assault with ladders. The lower part of the figure shows a platform. Also of note are the captions in the figures (from Galilei Opere, II, p. 25)
Between one bulwark and the next there can be other elements of defense, such as the piattaforma (platform), shown in the lower part of Fig. 2. An interesting and important part of the defensive system of city walls is the arrangement of the artillery, which can strike with either tiro di striscio (glancing fire) or tiro di ficco (direct fire). Glancing fire allows firing directly along the walls, so it is very effective when the attackers come to lean their ladders against the walls; direct fire can be aimed at a precise point on the curtain and is thus useful when the attackers attack a given point on the wall with pick-axes and zappa, saps, where it is generally difficult for the defenders to reach, so much so that Galileo writes that "direct fire is convenient and aimed at eliminating the attack by saps (zappe) and pick-axe, which is extremely significant and perhaps more important than all the others". 2

Galileo states that there are those who favour direct fire and those who champion glancing fire, but his advice is the following: "We could decide, to fulfil both needs, to make it so that there are cannon embrasures that for direct fire and others for glancing fire, as we will show in the construction of our bulwark". 3

Having provided these necessary explanations, Galileo arrives to the best way to construct a bulwark. This topic is quite interesting, because it concerns a problem of optimisation between two variables, such that when the optimum of one increases, that of the other decreases. Thus the problem is to find the correct strada di mezzo (middle road) (Galilei Opere, II, p. 29). Galileo is perfectly aware of the nature of the question, even though he does not provide even a rough sketch of a mathematical treatment. Thus, the situation is this: to be well defended, a bulwark must have the angle between its faces as little acute as possible (a fact that was also underlined by Tartaglia and Lorini, among others [14], 2009). This is because when cannon fire strikes the corner of the bulwark, if this angle is very acute, the blow can rather easily damage both faces, while if the angle is less acute, this eventuality is more remote. As Galileo writes, "if the angle is less acute, it will be less easily cut by the enemy". 4

On the other hand, he argues, the flank must be constructed as large as possible, where by large he means as far as possible beyond the curtain, so that, when glancing fire is used against the attackers, it is possible to use the largest possible cannon balls. However, if the flanks are

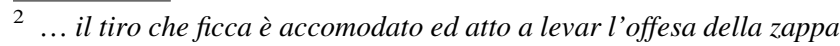
e piccone, la quale è grandissima e forse di più importanza di tutte l'altre (Galilei Opere, II, p. 31).

${ }^{3}$ Potremo determinare, per supplire all'uno e all'altro bisogno, di fare che ci siano cannoniere che ficchino, ed altre che striscino; come nella fabrica del nostro baluardo dimostreremo" (Galilei Opere, II, p. 31).

4 ...quando l'angolo sarà meno acuto, meno facil sarà esser tagliato dal nimico (Galilei Opere, II, p. 29). 
Fig. 3 Situations that lead to constructing a bulwark with a very acute angle: a top The angle of the bulwark can turn out to be very acute because it is constructed on the angle of a wall that is already very acute; the angle of the bulwark will then be even more acute (detail of Galilei Opere, II, p. 29); b middle the angle of the bulwark will be very acute when the flanks are very long (or large, to use Galileo's expression) (detail of Galilei Opere, II, p. 30); c bottom the angle can turn out to be very acute because of the desire to locate defences close to the curtain (detail of Galilei Opere, II, p. 30)

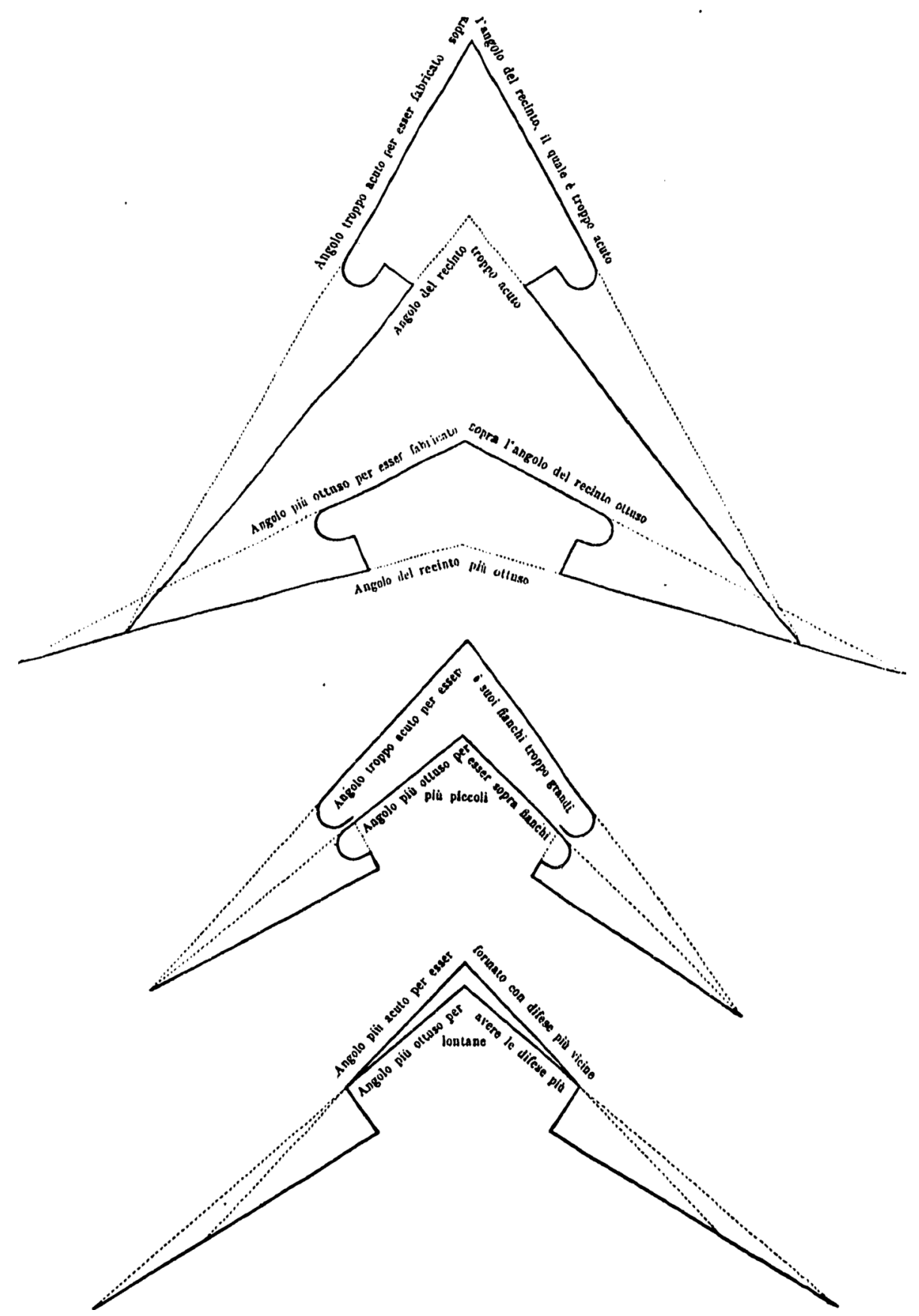

very long, the angle of the bulwarks tend to become more acute.

Another question is this: if the batteries of defense must be located as close as possible to the curtain, in order to be most effective, the acute angle is more suitable, as shown in Fig. 3c.

The situations that lead to making the angle of the bulwark more acute-something that in itself is negativeare thus: (1) when the bulwark is constructed on a wall whose angle is already very acute; it is in fact obvious that the angle of the bulwark will turn out to be more acute than that of the wall (Fig. 3a); (2) when the flank is very large
(Fig. 3b); (3) when the defences are placed very close to the curtain (Fig. 3c).

Thus the effectiveness of the bulwark is a function of three variables: the angle of the bulwark, the length of the flanks, and the closeness of the defences to the curtain. These variables are not, however, independent: as one increases, another decreases-although the functional nexus is never specified-and thus in designing the bulwark the architect must take the question into account and find a correct balance. Given the lack of a rigorous mathematical treatment, which was beyond the capabilities of the 
mathematicians at the end of the 16th century, it is remarkable that Galileo underlined clearly the complex functional relationship between the angle of the bulwark, its length, and the closeness of the defences to the curtain. In the sections dedicated to the best way to carry out an assault, Galileo explains how to construct the trenches and place the mines, after which he must grapple with the explanation of the phase of the actual assault. However, leading up to that, the Pisan scientist wishes to settle the question of a diatribe that divided the experts of military arts: there were those who maintained that, during the offensive phase, artillery was most efficient if fired from as close as possible, and those who maintained instead that a certain distance provided the most effectiveness. Galileo states that this second opinion is ridiculous, as made manifest by esperienza (experience) for those who wish to try, and by ragione (reason), if used properly. This is as to say that in problems that deal with the exterior world, pure reason cannot suffice, it is necessary to experiment; but that in itself is not enough, and it is necessary to reason correctly about these experiences: precisely sensate esperienze e dimostrazioni necessarie, sensate experiences and necessary proofs (or in any case, where there are no proofs, "necessary reasoning"). We close this section with Galileo's enlightening words:

But before we proceed to other matters, it appears suitable to me to say something about a curious dispute between some who make a profession as expert bombardiers: which is, if it is best to situate the artillery at the walls that it is desired to demolish, as close as possible, or, if remaining at a certain distance, comes to have a greater effect than being very close. And the reason of treating this is hearing that some are of the opinion, indeed, in their minds it is most certain, that the artillery makes a better pass when it is placed at a certain determined distance than if it is very close. This opinion, even though it has infinite authors, can only remain false, and in some way ridiculous: as experience, for those who wish to try it, and reason, for those who will discourse with correct judgement, can persuade. ${ }^{5}$

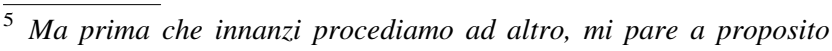
parlare alquanto intorno a una disputa curiosa che corra tra alcuni che fanno professione di bombardieri periti: la quale è, s'è meglio piantar l'artiglieria alla muraglia, che si vuol battere, più vicina che sia possibile; o pure, se stando lontana per una certa distanza, verrà a far maggior effetto ch'essendo molto vicina. E la cagione di trattar di ciò è il sentire ch'alcuni hanno per opinione, anzi pur nella mente loro come per cosa certissima, che l'artiglierie faccino maggior passata stando a una certa determinata lontananza, che se fossero più vicine: la qual opinione, ancor che abbia infiniti fautori, non resta però che non sia falsa, ed in un certo modo ridiculosa; sì come la esperienza, a chi far la vorrà, e la ragione a chi con retto giudizio discorrerà, può persuadere (Galilei Opere, II, p. 49, our emphasis).
}

\subsection{Trattato di fortificazione}

All of the Trattato di fortificazione is interesting because, even where Galileo reprises the topics of earlier workwhich occurs in the majority of cases-he often does it in a more in-depth and perspicuous way. First of all, Galileo explains the object:

\section{THE REASONS FOR ORDERING FORTIFICATIONS}

Because we must discourse about the way of fortifying, we must first of all put in our minds the aim, for which fortifications have been ordered: which is none other than making it so that few can defend themselves against many; ... Thus it is necessary that those of the fortress devise ways to be able to fight the enemy with the advantage of the site.

It is necessary, in addition to that, to know what kind of offensives are to be resisted ... that is, the battery, when the artillery opens a wall from far way, and by means of that opening makes an adit for entering the fortress; the spade [sap], which is made by coming next to the wall, and ruining it with iron rods, with pick-axes and other instruments; the fifth, finally, is the siege, when, removing from the defenders all sorts of succour, they are forced by hunger to surrender. Let us leave aside treason, as an ignominious way of expunging, and which evil cannot be remedied, it being impossible to guard against traitors. ${ }^{6}$

We have chosen to give an example of a topic that instead is not, practically speaking, analysed in the Breve instruzione: the various ways of erecting the elements of defense in relation to the site where they are to be erected (Galilei Opere, II, pp. 130-137). Galileo analyses diverse types of sites: (1) in the open countryside; (2) on a plain,

\footnotetext{
${ }^{6}$ LA CAGIONE PERCHÉ SONO ORDINATE LE FORTIFICAZIONI (Galileo Ms. 281, folia 2-4; Galilei Opere, II, p. 83).

Dovendo noi discorrere intorno al modo di fortificare, doviamo prima recarci inanzi alla mente il fine, per il quale sono state ordinate le fortificazioni: il quale altro non è che il fare che pochi possino difendersi da molti;... Adunque bisogna che quelli della fortezza s'ingegnino di poter contrastare al nimico co 'l vantaggio del sito.... Bisogna, oltre a ciò, sapere a quali sorte d'offese si deve resistere ... cioè, la batteria, quando con l'artiglierie s'apre di lontano una muraglia, e per l'apertura si fa adito per entrare nella fortezza ... la zappa, che si fa accostandosi alla muraglia, e con pali di ferro, con picconi, ed altri istrumenti, si rovina; ... la terza è la scalata, quando con le scale si monta sopra la muraglia; ... la quarta è la mina, la quale, per la forza del fuoco rinchiuso in una cava sotterranea (come a suo luogo dichiareremo), rovina in uno instante una muraglia;... la quinta finalmente è l'assedio, quando, togliendo a i difensori ogni sorte di sussidio, si constringono per la fame a rendersi. ... Lasciamo stare il tradimento, come maniera d'espugnare ignominiosa, ed alla quale male si può trovare rimedio, sendo impossibile guardarsi da $i$ traditori" (Galileo Ms. 281, folia 2-4; Galilei Opere, II, p. 83).
} 
but with nearby hollows; (3) close to mountains; (4) sites crossed by a river; (5) in a marsh or lake; (6) at seaports (the most difficult to defend). In what follows we will analyse the first two cases.

The section entitled "Diversi esempi d'accomodar i corpi di difesa secondo la diversità de' siti" (Diverse examples of adapting the elements of defense according to the diversity of sites) begins, as is often the case in these youthful works, with an epistemological consideration that is noteworthy and significant in relation to Galileo's works way of reasoning:

Considering the great force that sensate examples have to persuade and declare the thoughts of the mind, we have determined, to shed more light on our intention, to place before the eyes diverse designs of fortified places. ${ }^{7}$

Here again we find the concept of sensateness, which in Galileo means not only "related to or deriving from the senses" but also, with a significance still more current, something that has sense, or better, something that must be interpreted by giving it a sense; that is to say, an experience is not sensate in the absolute, but in relation to the context in which it is found and to the interpretative instruments used to contextualise it. In essence, it concerns: (1) the relationship between theory and practice; (2) the way in which man "intentionates" (to use the expression of BrentanoHusserl), that is, gives a sense to the objects before him or that he constructs. Galileo is aware that examples serve to render evident how well the theory functions, and that our aims, whether purely cognitive or practical, are fundamental for framing the relationship between practice and theory. This is as valid for "natural philosophy" (physics) as it is for questions that are less abstract, such as those appertaining to fortifications. Thus Galileo, given the precepts about how to construct defences, shows what happens in specific cases.

\subsubsection{A site in the open countryside}

Galileo presumes that the town, village or city to be fortified already has a wall constructed around it before the advent of artillery, and intends to fortify it "according to modern usage" (Fig. 4). First of all it is necessary to furnish the ancient curtains with bulwarks to be placed at corners A, B, E, F. However, the bulwark at E would turn out to be too acute if it were constructed on the corner of the old fortress, and thus it is necessary to

\footnotetext{
7 Considerando quanto abbiano grande forza gli essempi sensati in persuadere e dichiarare i pensieri dell'animo, abbiamo determinato, per dar maggior lume dell'intenzione nostra, recare innanzi a gli occhi diversi disegni de' luoghi fortificati (Galilei Opere, II, p. 130).
}

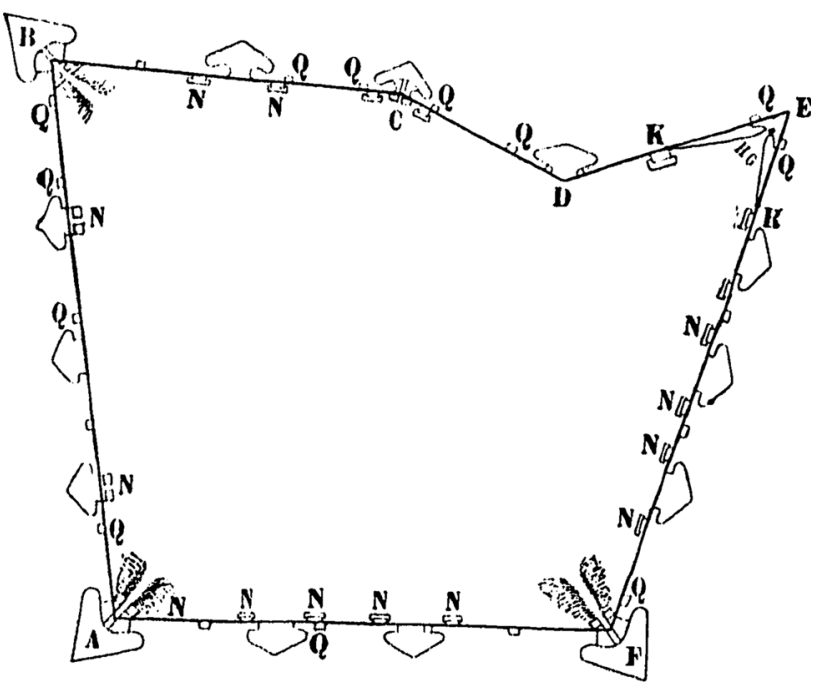

Fig. 4 "The most opportune way to erect defensive fortifications in a settlement located in the open countryside" (detail of Galilei Opere, II, p. 130)

construct two flanks that form an angle HG less acute than the original one, in order to be able to construct an effective bulwark. At $\mathrm{K}$ and $\mathrm{R}$ the new flanks conjoin to the old curtain. A defensive system is good if the elements of defense are not too far apart, and for such a small settlement, the bulwarks placed as described are too far apart, and thus it is necessary to add other defensive elements: the cavalieri, indicated by N. This is a raised structure that makes it possible to dominate the countryside and add batteries of support to those of the bulwarks. Galileo suggests that the maximum distance between one defensive structure and the next should not exceed 400 braccia. Medieval cities often had towers. When the times change, these towers were no longer effective; in fact, if they are too close to the flanks, such as those shown at $\mathrm{Q}$, they must be demolished because if they are brought down by artillery fire during an assault, they can do major damage to the defenders.

\subsubsection{A site on the plain with hollows nearby}

In this case it is necessary to protect the hollows near the settlement as well, so as to avoid their use by the enemy. So, with the heaviest continuous line indicating the old fortress and the area drawn in black the hollows (Fig. 5), it is necessary to erect bulwarks in areas A, B, E, D, C, so that it is possible to control the zones below the level of the settled and strike the enemy should need arise. The letter F indicates the cavaliero. The structure of bulwark GCE is so extensive and massive for two reasons: (1) to allow control of the hollow in front of the settlement; (2) to construct a fortification whose angle in $\mathrm{G}$ is not too acute, as it would 


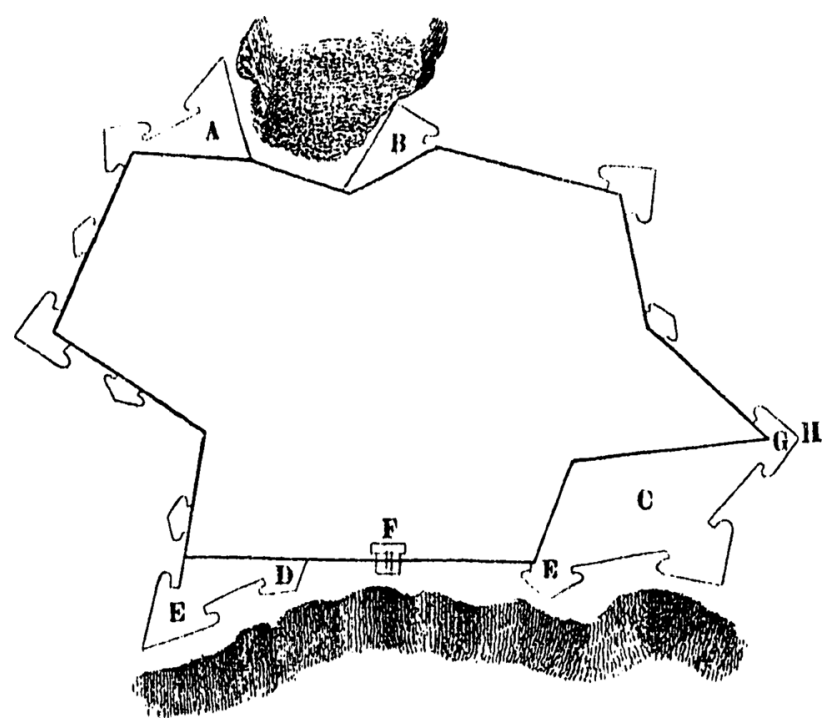

Fig. 5 Fortification of a site on a plain with nearby hollows (detail of Galilei Opere, II, p. 132)

turn out to be if the bulwark were constructed directly on the corner of the old walls.

\subsection{Le mecaniche}

For Le mecaniche we will not provide specific examples of the way in which Galileo explains the functioning of the machines that he analyses. Instead, we will highlight the principles that lie at the base of his work and which are very interesting with regard to the history of physics.

Galileo makes it clear from the very beginning of his work that one of the primary aims in writing is to clarify what operations a machine can do, in contrast to those which it cannot perform. This is due to the fact that many builders of machines-indeed, all of them, he means to say, where he uses the expression l'universale dei mecanici (Galilei Opere, II, p. 155)—deceive themselves by asking for the impossible. In particular, what their error comes down to is the belief that it is possible to raise heavy weights with a small force. Galileo is extremely clear in this regard:

Of those deceptions [those into which the builders of machines are led] it seems to me to have mainly understood the reason for the belief that these artisans have had, and still have, of being able with a small force to move and lift extremely heavy weights, in some way deceiving nature with their machines; an instinct of which, indeed, an extremely firm characteristic is that no resistance can be overcome by a force that is not more powerful than it. How false this belief is I hope, with true and necessary proofs, which we will have as we go along, to make most manifest. ${ }^{8}$

This quotation is very dense

1. First of all, Galileo was very familiar with Archimedes' On the Equilibrium of Planes and had considered at length (as his Mecaniche prove) the principle of the lever. He thus knew well that a weight can be lifted only if the moment of the lifting force is superior to that of the resisting force.

2. Galileo then notes that nature cannot be deceived. It is impossible, we would say today, with a small "force" to transport or move a heavy weight. It is well known that the concept of force is not well defined in Galileo's day, and would not be until Isaac Newton (1642-1727), but what Galileo wants to say is clear, and is a consideration that brings him close to those who thought to express physics in terms of principles, such as Simon Stevin (1548-1620) before Galileo, and as Gottfried Wilhelm von Leibniz (1646-1716) would do in the seventeenth century, albeit not in a complete and rigorous way: if a certain quantity of mechanical energy is introduced into a system, in optimum conditions, the final energy is equal to the initial energy; that is, energy cannot be created by means of the transformation of human work into the work of a machine. Put another way, work cannot be created from nothing. In other words, perpetual mechanical motion (to use Leibniz's words) is impossible. Galileo-obviously-does not express himself in these terms, nor does he know the variables at play on the level of the relationship between physics and mathematics [20], but the concept that he wishes to highlight is clear and very advanced, so much so in fact that it is completely unknown to "l'universo dei meccanici" (all mechanics).

3. Also of interest is the final part of the quotation where he explains how certainty can be achieved only by means of le dimostrazioni vere e necessarie (true and necessary proofs). This shows that Galileo's ideas about methodology were clear from his youth. However, while machines cannot produce energy from nothing - to express it in modern terms, but without betraying Galileo's thinking-it is true that they can

\footnotetext{
${ }^{8}$ Dei quali inganni [quelli in cui cadono i costruttori di macchine] parmi di avere compreso essere principalmente cagione la credenza, che $i$ detti artefici hanno avuta ed hanno continuamente, di poter con poca forza muovere ed alzare grandissimi pesi, ingannando, in certo modo, con le loro macchine, la natura; instinto della quale, anzi fermissima costituzione, è che niuna resistenza possa essere superata da forza, che di quella non sia più potente. La quale credenza quanto sia falsa, spero con le dimostrazioni vere e necessarie, che averemo nel progresso, di far manifestissimo (Galilei Opere, II, p. 155).
} 
transform it. This is their purpose, and it is one that is very useful for man. Galileo thus maintains that the use of machines is tied to four variables:

1. the weight (mass) that we wish to transfer from one place to another;

2. the force, or if we prefer, the concept of power-to use the terminology of the period that we are dealing with (an implicit condition, but not stated);

3. the distance that we wish this weight to travel;

4. the time that we have available.

Here again, as in the case of the relationship between the angle and the length of the bulwark, Galileo understands that they are not independent variables; that is, there is no ideal situation that consists in transporting a heavy weight with a small force for a long distance in a short interval of time. Due to the intrinsic necessities of nature, that is, physical principles, this is not possible.

Galileo thus maintains:

1. if we must transport a heavy weight from one place to another, but there is no need to perform the operation in a short interval of time, and we can subdivide the weight, then a machine, even one with a reduced force, as a man, can do it in a certain number $n$ of trips, transporting fractions of $1 / n$th of the overall weight.

2. if we wish to transport that same weight as a single whole with a machine that has a force exactly equal to $n$ times that of man, this machine will be able to transport the weight as a whole, but in exactly the same amount of time as the man. Anyone who hoped to transport the weight as a whole faster with such a machine than a man could do dividing the weight into $n$ parts, is deceiving himself.

3. machines can then be used to make certain operations easier. Galileo uses the example of a well that must be emptied. To be sure it is possible to use buckets and repeat the operation a number of times, or to use a pump that will draw the water out, which is easier for obvious reasons. However, in this case as well Galileo explains that:

...whoever believes he is able with any kind of machine to draw out, with the same force, in the same amount of time, a greater quantity of water, he is in grave error; and the more often and more deeply he finds himself deceived, the more he will go on imagining the most diverse and multiplied inventions. ${ }^{9}$

\footnotetext{
9 ...qualunque credesse di potere con machine di qual si voglia sorte cavare, con l'istessa forza, nel medesimo tempo, maggior quantità di acqua, costui è in grandissimo errore; e tanto più spesso e tanto maggiormente si troverà ingannato, quanto più varie e moltiplicate invenzioni anderà imaginandosi (Galilei Opere, II, p. 157).
}

4. Finally, machines make it possible to save in economic terms, which is the most important thing from the point of view of society, but has less need of physical explanations.

In the final analysis-and without attributing to Galileo concepts that are not stated or historically false as commonly occurs for illustrious scientists of his calibre-it seems reasonable to us to underline how Galileo leaves the modern reader to intuit his comprehension and capacity to handle functional nexuses among the physical variables observed, and the mathematics (arithmetic, proportions, including geometry) used. This characteristic is present in both the didactic works applied to military architecture, and in the studies of motion and equilibrium. We thus quote, without comment, a passage from Le mecaniche, in which Galileo makes a statement that very closely recalls the modern principle of inertia-even though with reference to motion along a terrestrial circumference and not in along a straight line, as Newton will do. This work of iuvenilia goes in the direction that Newton would take it (not René Descartes (1596-1650), as might be thought, seeing as how Descartes lacked the concept of force, while the full understanding of the principle of inertia requires the concept of force) to correctly formulate the principle of inertia. Galileo writes:

Since we have a surface that is quite clear and clean, like that of a mirror, and a ball that is perfectly round and smooth, of either marble or glass, or a similar material that remains clean, when this is placed on a given surface, it will go along moving, as long as that [surface] has a slight incline, even minimal, and will only stop on that surface which is exactly level and equidistant from the plane of the horizon; such, for example, will be the surface of a frozen lake or marsh, on which said spherical body will remain still, but disposed to be moved by any extremely small force. $^{10}$

\subsection{Le operazioni del compasso geometrico et militare}

Galileo's geometric and military compass has a recto and a verso. It has a series of lines, whose construction we will explain. It should be underlined that all the lines are

\footnotetext{
${ }^{10}$ Sì che avendo noi una superficie molto ben tersa e polita, quale saria quella di uno specchio, ed una palla perfettamente rotonda e liscia, o di marmo o di vetro, o di simile materia atta a pulirsi, questa, collocata sopra la data superficie, anderà movendosi, purché quella abbia un poco d'inclinazione, ancorché minima, e solamente si fermerà sopra quella superficie, la quale sia esattissimamente livellata, ed equidistante dal piano dell'orizonte; quale, per essempio, saria la superficie di un lago o stagno agghiacciato, sopra la quale il detto corpo sferico staria fermo, ma con disposizione di essere da ogni piccolissima forza mosso (Galilei Opere, II, p. 179).
} 
a

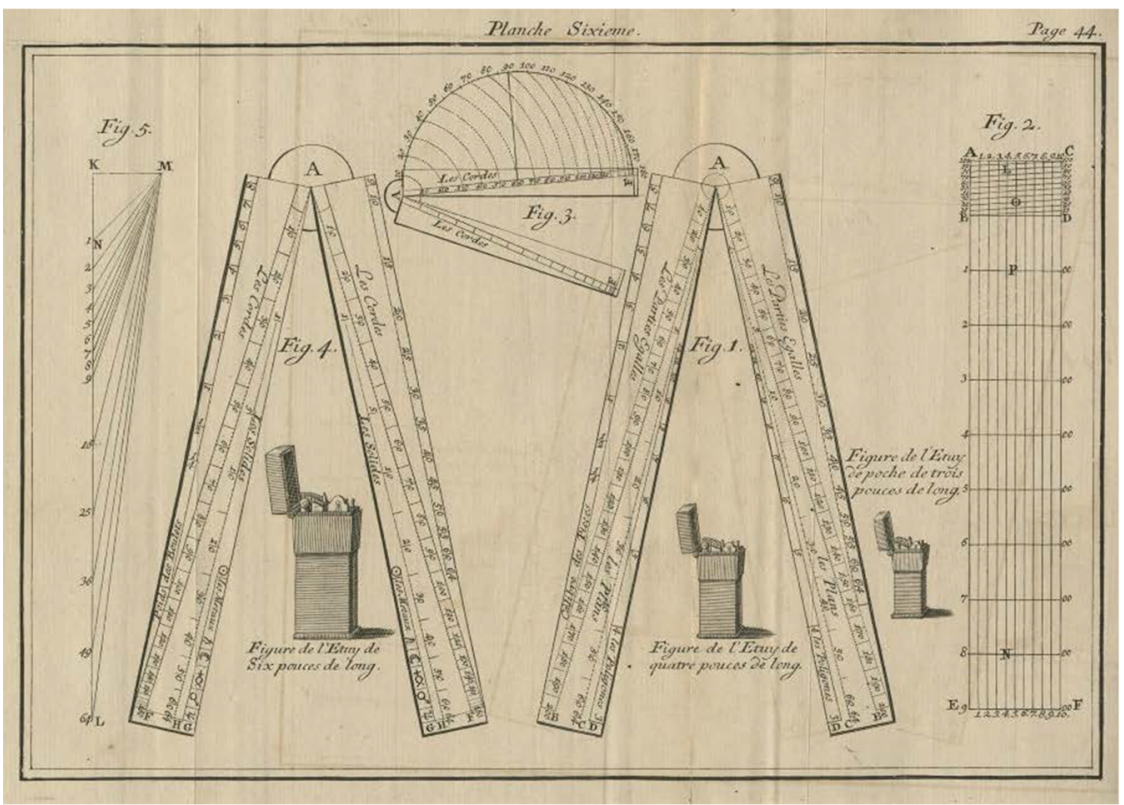

b

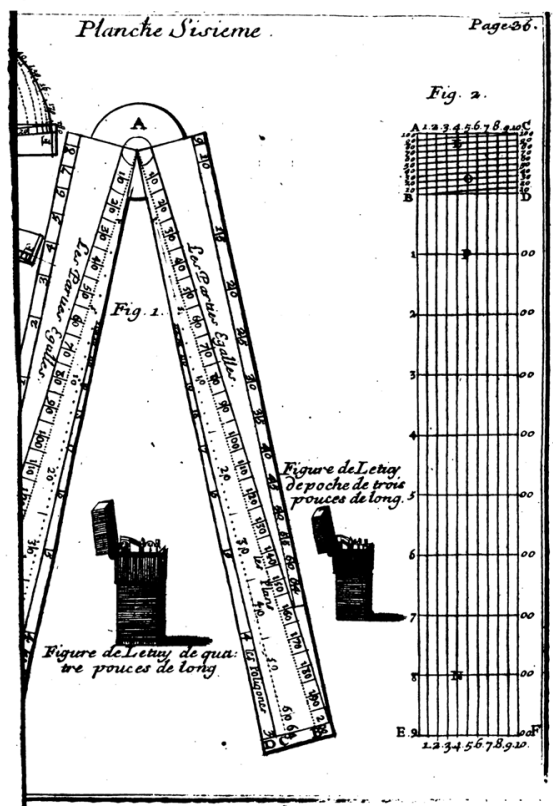

Fig. 6 a The proportional compass conceived by Galileo, as shown in Bion (1723, Pl. 6). Reproduced by kind permission of the Museo Galileo, Florence, http://catalogue.museogalileo.it/gallery/ProportionalCompasses_n01.html. b Galileo 1587, Tav. VI, p. 36, from: Bion 1725, 36v

proportional scales. As Galileo notes in the preface to the reader at the beginning of the work:

It only pains me to underline, good reader, that, however much I worked to explain the things that follow with all clarity and facility possible, in any case to those who must derive from the writing, some things will remain enveloped in obscurity, losing thereby much of that grace that, in seeing it actually used and learning about it by live voice, renders it marvellous. ${ }^{11}$

Never were truer words written. In spite of the image that we show in Fig. 6, the full explanation of how the compass works is much facilitated by seeing it in person, or today, in video. For this reason we refer the reader to the website of the Institute and Museum of the History of Science in Florence (http://brunelleschi.imss.fi.it/esplora/ compasso/) for this important aspect and other information.

The recto shows:

the arithmetic lines, on which are marked integers up to 250;

the geometric lines located in a more exterior position immediately next to the arithmetic lines, and numbered

\footnotetext{
11 Duolmi solamente sottolineare, benigno lettore, che, quantunque io mi sia ingegnato di spiegare le seguenti cose con ogni chiarezza e facilità possibile, tuttavia a chi le dovrà dalla scrittura cavare, resteranno in qualche oscurità involte, perdendo appresso molta di quella grazia, che nel vederle attualmente operare e nell'apprenderle dalla viva voce, le rende meravigliose (Galilei Opere, II, p. 370).
}

from 1 to 50 . Their primary function is that of indicating the sides of the squares whose areas are the indicated numbers. Thus the distance from the centre of the compass to each of the indicated numbers represents the square root of that number;

the stereometric lines, even further towards the exterior, marked with numbers up to 140 , and indicate the sides of the cubes whose volume is the indicated number. Thus the distance from the centre of the compass to each of the numbers indicated equals the cube root of the numbers shown.

the metallic lines, which are marked with the names of eight materials: gold, lead, silver, copper, iron, tin, marble and stone. Given a constant weight $\mathrm{P}$, each mark on the line indicates the diameter of a sphere of one of the eight materials whose weight is $P$. The marks closest to the centre of the compass thus indicate the materials with a greater specific weight, which decreases moving away from the centre.

The verso shows:

the polygraphic lines, marked closest to the inside, which carry the radii of circles circumscribing regular polygons having the same side, from the triangle to the polygon with fifteen sides. They are used to divide the circumference of a circle into a desired number of equal parts;

the tetragonic lines, located immediately next to the polygraphic lines, indicate, given a certain surface $S$, the 
sides of the regular polygons that have that surface, from the triangle up to the polygon with thirteen sides;

the added lines have an internal and an external scale; the external scale, divided into twenty equal parts, is marked with the heights of the arced portion of twenty circular segments with the same chord; on the internal scale are marked the twenty squares whose areas are equal to those of the respective circular segments. This is used to find the area of circular segments.

There is also a quadrant that can be applied to the compass. This quadrant serves four purposes: the bombardiers' square; the astronomical quadrant; the scale of inclines, and the square of shadows. For more in-depth descriptions, we refer the reader to the website of the Institute and Museum of the History of Science in Florence mentioned earlier.

Among the thirty-two operations described by Galileo, we will provide the example of two concerning the polygraphic lines.

1. Operation XXVI: describe a regular polygon of any number of sides $n$, given side $\mathrm{AB}$ of the polygon. The procedure is the following: put $\mathrm{AB}$ transversal to the points marked 6-6; the segment that joins the points marked $n-n$ indicates the length of the radius of the desired circle. In fact, the line that conjoins points 6-6 indicates the side of the inscribed hexagon, and thus the radius of the circumscribed circle. Then, because of how the polygraphic lines are constructed, the line $n-$ $n$ indicates the radius of the circle circumscribed about the $n$-gon whose side in $A B$. If, for example, we wish to construct the regular heptagon with side $A B$, we place $\mathrm{AB}$ transversal to 6-6; line 7-7 thus indicates the radius of the circle that circumscribes the heptagon. At this point, having drawn the circle and knowing the length of the side, it is possible to construct the heptagon with an ordinary compass.

2. Operation XXVII: divide the circumference into a given number of equal parts. This operation is the converse of the previous one, that is, we apply transversally to 7-7 the radius of the given circle, and segment 6-6 will be what will divide the circumference into seven equal parts.

These two examples show the ease with which Galileo's compass allows us to perform operations that cannot be carried out with only the use of compass and straightedge.

\section{Conclusion}

Our aim in this paper was to cover an important step in the early scientific life of Galileo, one without which his later works could not be explained. On the basis of recent publications (for example, see the works of Raffaele Pisano in the bibliography) and other researches of ours, we have shown the historic context and epistemological interpretation of Galileo's period in Padua. A forthcoming special issue of Philosophia Scientiae out in 2017, edited by the authors of this present paper, devoted precisely to the $I u$ venilia (including fortifications) will also celebrate the 450th anniversary of Galileo.

Translated from the Italian by Kim Williams.

\section{For further reading}

The following references presented here are essentially limited to Galileo's works and to the topics examined in this present paper. We have no pretence of being exhaustive, but only to provide the reader with some ideas for further study. The reader can thus see the diversity of approaches and methods used in the interpretation of the topics and works treated herein.

\section{References}

\section{On Galileo and his work}

1. Bion, N.: Traité de la construction et des principaux usages des instruments de mathematiques. La Haye, Husson (1723)

2. Drake, S.: Galileo's experimental confirmation of horizontal inertia. Isis 64, 291-305 (1973)

3. Galilei, G.: Le Opere di Galileo Galilei: Edizione nazionale sotto gli auspici di sua maestà il re d'Italia, vols. 20. Firenze, La Barbèra (1890-1909)

4. Galilei, G.: Dialogues Concerning Two New Sciences. Henry Crew and Alfonso de Salvio, trans. New York, MacMillan (1914)

5. Galilei, G.: Galileo Galilei. Le Mecaniche. Gatto, R. (ed.) Firenze, Olschki (2002)

6. Galilei, G.: Ms. A-Trattato di fortificazioni e modo d'espugnare la città con disegni e piante di fortificazioni. Biblioteca Ambrosiana. D: 328 Inf.-38640 (fl. 16th)

7. Galilei, G.: Ms. B-Trattato delle fortificazioni, con disegni diversi. Biblioteca Ambrosiana. D: 296 Inf.-38499 (fl. 16th)

8. Galilei, G.: Ms. m-Trattato di fortificazioni, con disegni e figure (acephalous). Biblioteca Ambrosiana. N: 281 Sup.-2-80277 (fl. 16th)

9. Gille, G.: Les ingénieurs de la Renaissance. Paris, Hermann (Eng. ed. The Renaissance Engineers. MIT Press, Cambridge, 1966) (1964)

10. Hill, D.K.: Galileo's work on 116v: a new analysis. Isis 77, 283-291 (1986)

11. Hill, D.K.: Dissecting trajectories: Galileo's early experiments on projectile motions and law of fall. Isis 79, 646-668 (1988)

12. Hogg, I.: Storia delle Fortificazioni. Novara, Istituto Geografico De Agostini (1982) 
13. Naylor, R.H., Drake, S.: Discussion on Galileo's early experiment on projectile trajectories. Ann. Sci. 40, 391-396 (1983)

14. Pisano, R.: Il ruolo della scienza meccanica nella progettazione degli architetti e degli ingegneri del Rinascimento, vols. 2. Università di Roma "La Sapienza", Roma. E-book: International Galilean Bibliography. Istituto e Museo di Storia delle Scienze, Firenze. http://biblioteca.imss.fi.it/. Print book: Direction des collections, Département Sciences \& Techniques, Bibliothèque Nationale de France, Paris, référence: DDD-TOL-2011-94, p. 18 (2008)

15. Renn, J., Valleriani, M.: Galileo and the challenge of the arsenal. Nuncius, XVI 2, 481-503 (2001)

\section{Other works on the topics covered herein by the present authors:}

16. Capecchi, D., Pisano, R.: Scienza e tecnica nell'architettura del Rinascimento, CISU, Roma (2010)

17. Pisano, R.: On method in Galileo Galilei's mechanics. In: Hunger, H. (ed.) Proceedings of ESHS 3rd Conference, pp. 147-186. Austrian Academy of Science, Vienna (2009a)

18. Pisano, R.: Galileo Galilei. Riflessioni epistemologiche sulla resistenza dei corpi. In: Giannetto, E., Giannini, G., Toscano, M. (eds.) Relatività, Quanti, Chaos e altre Rivoluzioni della Fisica. Rimini, Guaraldi, pp. 61-72 (2009b)

19. Pisano, R.: Il ruolo della scienza archimedea nei lavori di meccanica di Galilei e di Torricelli. In: Giannetto, E., Giannini, G., Capecchi, D., Pisano, R. (eds.) Da Archimede a Majorana: La fisica nel suo divenire (Proceedings of XXVI SISFA Congress). Rimini, Guaraldi, pp. 65-74 (2009c)

20. Pisano, R.: Physics-Mathematics relationship. historical and epistemological notes. In: Proceedings of the ESU 6 - European Summer University History and Epistemology in Mathematics (curato da E. Barbin, M. Kronfellner, and C. Tzanakis). Verlag Holzhausen GmbH-Holzhausen Publishing Ltd., Vienna, pp. 457-472 (2011)

21. Pisano, R., Bussotti, P.: On Theoremata Circa Centrum Gravitatis Solidorum and Mysterium Consmographicum. In: History Research, 2/2:1, pp. 110-145 (2012)

22. Pisano, R., Capecchi, D.: Il ruolo della meccanica ne Le Fortificazioni di Buonaiuto Lorini. In: Atti del $3^{\circ}$ Convegno di Storia dell'Ingegneria (ed. S. D’Agostino), vol. II. Cozzolin, Napoli, pp. 797-808 (2009)

23. Pisano, R., Capecchi, D.: Galileo Galilei: notes on Trattato di Fortificazione. In: Altamore, A., Antonini, G. (eds.) Galileo and the Renaissance Scientific Discourse. Edizioni Nuova Cultura, Roma, pp. 28-41 (2010)

24. Pisano, R., Capecchi, D.: Historical Reflections on the Scale Ratio in Galilean Trattato di Fortificazioni. In: Koestler, T., Ceccarelli, M. (eds.) Explorations in the History of Machines and Mechanism (Proceedings of HMM 2012). Springer, Dordrecht, pp. 463-473 (2012a)

25. Pisano, R., Capecchi, D.: Il Trattato di Fortificazione di Galileo Galilei. In: d'Agostino, S. (ed.) Atti del $4^{\circ}$ Convegno Nazionale di Storia dell'ingegneria, vol. I, pp. 77-90. Cozzolin, Napoli (2012b)

26. Pisano, R., Capecchi, D.: Tartaglia's Science of Weights and the Mechanics in the Sixteenth Century. Selections from Quesiti et invention diverse: Books VII-VIII. Springer, Dordrecht (2015, in press)

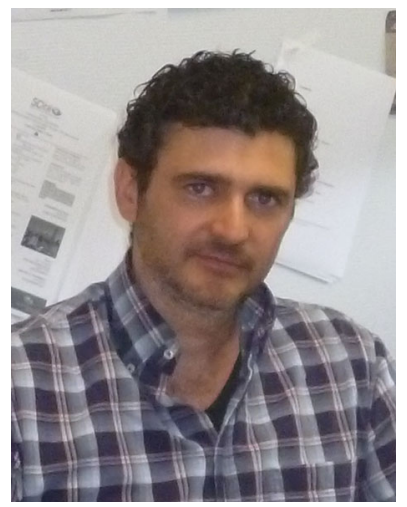

Raffaele Pisano physicist, is a qualified historian, lecturer researcher of history of physics, epistemology of science at the University of Lille 1, France. Vice President of Inter-Divisional Teaching Commission (DLMP/IUHPST). Former head of Research Centre for the Theory and History of Science, University of Plzen, Czech Republic. Fields: history and historical epistemology of sciences. His recent works include "Newton's Philosophiae Naturalis Principia Mathematica "Jesuit" Edition: The Tenor of a Huge Work", Rendiconti Lincei Matematica e Applicazioni, with Paolo Bussotti; Lazare and Sadi Carnot. A Scientific and Filial Relationship (Springer) with Charles Gillispie; The Dialectic Relation between Physics and Mathematics in The XIXth Century (Springer). In press: Tartaglia's Science of Weights and Mechanics in SixteenthCentury. Selections from Quesiti et inventioni diverse: Books VII-VIII (Springer); A Bridge between Conceptual Frameworks, Science, Society and Technology Studies (Springer). More info: http://fr.linkedin. com/pub/raffaele-pisano/6/a11/a61/.

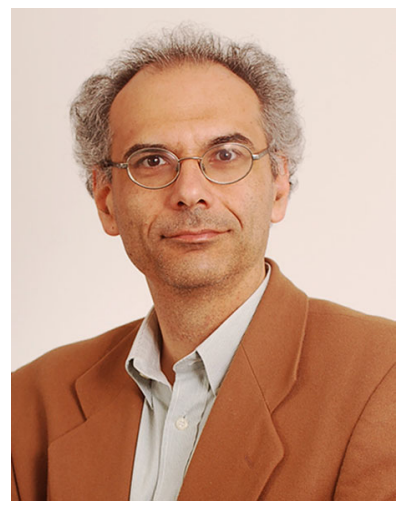

Paolo Bussotti historian of science and mathematics, former Alexander von Humboldt Fellow at the Ludwig Maximilians University in Munich and Berlin-Brandenburg Academy of Sciences, Berlin. His recent work includes: From Fermat to Gauss: indefinite descent and methods of reduction in number theory (Rauner), Un mediocre lettore. Le letture e le idee di Federigo Enriques (Agorà-Lumieres). The influence of Spinoza's concept of infinity on Cantor's set theory (SHPS, with Tapp). With Raffaele Pisano: "Galileo and Kepler: On Theoremata Circa Centrum Gravitatis and Mysterium Cosmographicum" (History Research), "On the Jesuit Edition of Newton's Principia. Science and Advanced Researches in the Western Civilization" (Advances in Historical Studies), Newton's Philosophiae Naturalis Principia Mathematica "Jesuit" Edition: The Tenor of a Huge Work (Rendiconti Lincei Matematica $e$ Applicazioni). 